\title{
The Risk Level of Breast Cancer and Breast Cancer Awareness Among the Turkish Women Aged 65 Years and Older
}

\author{
Nuriye B. DUMAN' ${ }^{1}$, Gulay YILMAZEL ${ }^{2}$, Gul PINAR ${ }^{3}$, Lale BUYUKGONENC ${ }^{4}$ \\ ${ }^{1}$ Hitit University, School of Health, Department of Nursing, Corum \\ ${ }^{2}$ Hitit University, School of Health, Department of Nursing, Corum \\ ${ }^{3}$ Yıldırım Bayezıt University, Faculty of Health Sciences, Department of Nursing, Ankara \\ ${ }^{4}$ Koc University, School of Nursing, Istanbul, TURKEY
}

\begin{abstract}
This study was conducted in order to determine risk level of breast cancer and breast cancer awareness among the women aged $\geq 65$ years. The sample of the study was composed of 445 women aged over $\geq 65$ years. The data were gathered with Breast Cancer Risk Assessment Tool and Champion's Health Belief Model Scale for breast cancer (HBMS) and were evaluated with percentages and Kruskal Wallis test. It was found out that $1.6 \%$ of the women were under high risk while $2.7 \%$ of them were under very high risk for breast cancer. Breast cancer risk for those with personal breast cancer history was very high (mean risk score (MRS): $549.58 \pm 48.26$ ) and breast cancer risk level of the women whose mothers and sisters had breast cancer history was high (MRS: $328.46 \pm 107.02$ ). It was noted in the study that as women's breast cancer risk level went up so did their mean HBMS scores for susceptibility and health motivation $(p<0.05)$. Women who had personal breast cancer history, whose family members had breast cancer history, whose menarche ages were $\leq 11$ years, who gave the first birth after the age of 30 had higher MRS as compared with the other women. Those who were susceptible to breast cancer and whose health motivation was high showed higher risk for breast cancer.
\end{abstract}

Keywords: Breast cancer, Risk level, Awareness, 65 years and older

\section{ÖZET}

65 Yaş ve Üzeri Kadınların Meme Kanseri Risk Düzeyleri ve Meme Kanserine Yönelik Farkındalıkları

Bu çalışma, 65 yaş ve üzeri kadınların meme kanseri risk düzeylerini ve meme kanserine yönelik farkındalıklarını belirlemek amacıyla yapılmıştır. Araştırmanın örneklemini 65 yaș ve üzeri 445 kadın olușturmuștur. Veriler, Meme Kanseri Risk Düzeyini Belirleme Formu, Champion'un Meme Kanserine Ilişskin Sağlık Inanç Modeli Ölçeği (SiMÖ) kullanılarak toplanmış ve yüzdelik oranlar, aritmetik ortalama, standart sapma ve Kruskal Walls testi ile değerlendirilmiştir. Çalışmada kadınların meme kanseri açısından \% 1.6'sı yüksek ve \% 2.7'si ise çok yüksek risklidir. Ayrıca kişisel meme kanseri olan kadınların meme kanseri risk düzeyi çok yüksek (ORP: $549.58 \pm 48.26$ ), anne ve kız kardeşinde meme kanseri öyküsü olan kadınların (ORP: $328.46 \pm 107.02)$ ise meme kanseri risk düzeyi yüksek bulunmuștur. Kadınların meme kanseri risk düzeyi arttıkça SiMÖ duyarlıık algııı ve sağlık motivasyonu puan ortalamalarının da arttı̆̆ı tespit edilmiştir ( $p<0.05)$. Çalışmada kişisel meme kanseri öyküsü olan, aile hikayesinde meme kanseri olan, menarş yaşı 11 ve altı olan ve ilk doğumunu 30 yaş sonrası yapan kadınların meme kanseri açısından ORP'ı diğer kadınlara göre daha yüksektir. Ayrıca çalışmada meme kanserine karşı duyarlı olan ve sağlık motivasyonları yüksek kadınların meme kanseri risk düzeyi yüksek olan kadınlar oldukları tespit edilmiştir.

Anahtar Kelimeler: Meme Kanseri, Risk Düzeyi, Farkındalık, 65 yaş ve üzeri 


\section{INTRODUCTION}

Today it is obvious that cancer incidence among both genders has increased with the advanced age. Particularly for women advanced age emerges as an important cancer risk factor for gynecological cancers. The most commonly seen cancer type among the women aged $\geq 65$ is breast cancer. ${ }^{1-4}$ Breast cancer was the most commonly diagnosed cancer type among the women aged $\geq 65$ in the USA between 2000 and 2007. 2-4 Although breast cancer incidence among women goes up following the age of 40 it decreases after the age of 75.5 Breast cancer incidence is 160 per 100.000 among the women aged 50 and 60 years while it is 200 per 100.000 among the women aged $65-74 .^{6}$ In Turkey breast cancer ranks first among the most commonly seen cancer types among women with an incidence of $41.8 \%$. The incidence rate is 79.5 per 100.000 among the women aged 40 and 44 while it may increase to 127.9 per 100.000 among the women aged 65 and $68 .^{7}$ In addition to the advanced age other risk factors that play a role in the development of breast cancer are being female, familial breast cancer history, atypical hyperplasia, mutation in BRCA-1 and BRCA-2 genes, extended interval period between menarche and menopause, nulliparity, giving the first birth after the age of 30 and obesity. It is reported that coexistence of one or more of these risk factors with the advanced age increases breast cancer risk. ${ }^{8,9}$

Today, it is possible to detect breast cancer early thanks to the advancements in technology and early detection and screening methods. Routine mammography reduces breast cancer mortality rate by 25-30\% among the women aged between 50 and 75 years. ${ }^{5}$ In fact increase in fatty tissue in the elderly women makes it much easier for them to detect breast cancer at an early period by performing breast self-examination (BSE) and having mammography. BSE and screening mammography provide an early detection with high positive results particularly among the elderly women with high risk for breast cancer. Gerontologists and oncologists recommend monthly BSE, annual clinical examination and mammography once in two years for the elderly women. ${ }^{5}$ Screening mammography should be performed for all of the women whose life expectancy is over four years. ${ }^{10}$ However the studies done indicate that women in the geriatric age group do not have sufficient level of awareness of breast cancer and screening methods..$^{1-4}$ Therefore it is very important to explore the high risk groups in terms of breast cancer, to increase women's breast cancer awareness and to popularize the early detection methods in preventing early mortality caused by breast cancer. When the literature was investigated it was noted that the number of the studies done on breast cancer among the women in geriatric age group was small ${ }^{11-13}$ which was the indicative factor to plan the current study. Our study was conducted in order to determine level of breast cancer risk and breast cancer awareness among the women aged 65 years and older.

\section{PATIENTS AND METHODS}

This study was descriptively conducted in order to determine risk level of breast cancer and breast cancer awareness among the women aged $\geq 65$ years. The population of the study was composed of women aged $\geq 65$ years who presented to Internal Diseases Unit/Geriatrics Unit and Early Diagnosis and Screening Center for Cancer of the Research and Training Hospital of Hitit University. The sample of the study was composed of 445 aged women who were recruited with random sampling method and volunteered to participate in the study. To calculate the sample size power analysis technique $(80 \%)$ was used.

The data were gathered with Breast Cancer Risk Assessment Tool (BCRAT), Champion's Health Belief Model Scale for Breast Cancer and Breast Cancer Screening (HBMS) and Form of Demographic and Obstetrics Characteristics investigating the women's demographic and obstetrics characteristics designed by the researcher in line with the literature.

The data obtained were assessed with SPSS 17.0 statistical package software. For the data analyses percentages, arithmetic means and standard deviations were employed. As for the data that did not follow a normal distribution Kruskal Wallis test was used. 


\begin{tabular}{|c|c|}
\hline Risk Factors & Category Score \\
\hline \multicolumn{2}{|l|}{ Age } \\
\hline$<30$ & 10 \\
\hline $30-40$ & 30 \\
\hline $41-50$ & 75 \\
\hline $51-60$ & 100 \\
\hline $60 \geq$ & 125 \\
\hline \multicolumn{2}{|l|}{ Familial Breast Cancer History } \\
\hline No & 0 \\
\hline $\begin{array}{l}\text { One maternal and or paternal } \\
\text { aunt/grandmother }\end{array}$ & 50 \\
\hline Mother or sister & 100 \\
\hline Mother and sister & 150 \\
\hline Mother and two sisters & 200 \\
\hline \multicolumn{2}{|l|}{ Personal breast cancer history } \\
\hline No & 0 \\
\hline Yes & 300 \\
\hline \multicolumn{2}{|l|}{ Age of giving birth } \\
\hline First birth before the age of 30 & 0 \\
\hline First birth after the age of 30 & 25 \\
\hline No child & 50 \\
\hline \multicolumn{2}{|l|}{ Menstruation age } \\
\hline$\geq 15$ & 15 \\
\hline $12-14$ & 25 \\
\hline$\leq 11$ & 50 \\
\hline \multicolumn{2}{|l|}{ Body structure } \\
\hline Underweight & 15 \\
\hline Normal & 25 \\
\hline Overweight & 50 \\
\hline
\end{tabular}

\section{Breast Cancer Risk Assessment Tool (BCRAT)}

Breast Cancer Risk Assessment Tool designed by American Cancer Society includes six dimensions and 20 items: age, familial breast cancer history, personal breast cancer, age of giving birth, age of menstruation and body structure ${ }^{14}$ (Table 1). Each dimension includes different risk factors for breast cancer and the scoring is accordingly done. A score below 200 is considered low risk, a score between 201 and 300 is considered moderate risk, a score over 301 and 400 is considered high risk and a score $\geq 400$ is considered the highest risk.

\section{Champion's Health Belief Model Scale for Breast Cancer and Breast Cancer Screening (HBMS)}

HBMS was introduced by Champion (1984) basing on health belief model including beliefs about early detection of breast cancer. ${ }^{15}$ Cronbach alpha reliability coefficients of HBMS for the six dimensions are between 0.69 and 0.83 . HBMS is consisted of eight subscales and 57 items: susceptibility (3 items), seriousness (6 items), health motivation (5 items), barriers of BSE (8 items), benefits of BSE (4 items), BSE self-efficacy (10 items), benefits of mammography (5 items), barriers to mammography (11 items). The scale is 5-point Likert-type scale. The option "I strongly disagree" is 1 point, "I disagree" is 2 point, "I am undecided" is 3 point, "I agree" is 4 point and "I strongly agree" is 5 point. Higher scores indicate that susceptibility and seriousness have increased and thus patients perceive benefits of and barriers to BSE, benefits of and barriers to mammography, BSE self-efficacy and health motivation at a high level.

\section{Ethical Consideration}

The research protocol was reviewed and approved by the Institutional Review Boards of the medical center and county board of education. The Principles set out by the Declaration of Helsinki and national and local ethical guidelines for research were also followed. All patients were informed of the purpose the study with written documents and were told that the information would not be disclosed and their oral consents were obtained.

\section{RESULTS}

Mean age of the participant women was $66.53 \pm$ 5.66. Nearly one of the two women was illiterate $(51.5 \%)$. Most of the women were married (72.6\%) and nearly all of them were multigravida and multipara (98.2\%). Also nearly 9 of the ten women's menopause duration ranged between 15 and 20 years $(89.9 \%)$ (Table 2$)$.

It was detected that nearly 8 of the ten participant women were in the low risk group for breast cancer $(79.8 \%) .16 .0 \%$ of the women were in the moder- 


\begin{tabular}{|c|c|c|c|}
\hline \multicolumn{2}{|l|}{ Characteristics } & \multirow{2}{*}{$\begin{array}{l}\mathbf{N} \\
430\end{array}$} & \multirow{2}{*}{$\begin{array}{l}\% \\
99.6\end{array}$} \\
\hline Age *(years) & $65-70$ & & \\
\hline & $71-76$ & 12 & 2.7 \\
\hline & $\geq 77$ & 3 & 0.7 \\
\hline \multirow{4}{*}{$\begin{array}{l}\text { Educational } \\
\text { status }\end{array}$} & Illiterate & 229 & 51.5 \\
\hline & Literate & 82 & 18.4 \\
\hline & Primary school & 120 & 27.0 \\
\hline & High school and above & 14 & 3.2 \\
\hline \multirow[t]{3}{*}{ Marital status } & Married & 323 & 72.6 \\
\hline & Single & 10 & 2.2 \\
\hline & Divorced & 112 & 25.2 \\
\hline \multirow[t]{2}{*}{ Gravida } & Primigravida & 8 & 1.8 \\
\hline & Multigravida & 437 & 98.2 \\
\hline \multirow[t]{2}{*}{ Parity } & Primipara & 8 & 1.8 \\
\hline & Multipara & 437 & 98.2 \\
\hline \multirow{2}{*}{$\begin{array}{l}\text { Menopause } \\
\text { duration (years) }\end{array}$} & $15-20$ & 400 & 89.9 \\
\hline & $21-2$ & 45 & 11.1 \\
\hline Total & 445 & 100.0 & \\
\hline
\end{tabular}

ate risk group while $1.6 \%$ of them were in the high risk group and $2.7 \%$ of them were in the very high risk group in terms of breast cancer.

According to findings related to the women's mean risk scores (MRS) of breast cancer mean risk score (MRS) of the women aged over 60 was 371.04 \pm 28.7 . $16.4 \%$ of the women had familial breast cancer history. MRS of those with familial breast cancer history (mother's and sister's breast cancer history) $(8.8 \%)$ was $328.46 \pm 107.02$, MRS of those with familial breast cancer history (maternal and paternal aunts' and grandfathers' breast cancer history) (6.3\%) was 261.79 \pm 94.34 . MRS of those who did not have familial breast cancer history was $179.76 \pm 29.05 .2 .7 \%$ of the women had personal breast cancer history. MRS of those who had personal breast cancer history was $549.58 \pm 48.26$ while MRS of those who did not have personal breast cancer history $(97.3 \%)$ was $190.76 \pm 24.70$. $5.6 \%$ of the women gave their first birth after the age of 30. MRS of those who gave their first birth after the age of 30 was $241.00 \pm 101.86$ while MRS

Table 3. Distribution of Women's Breast Cancer Risk Scores

\begin{tabular}{|c|c|c|c|c|c|}
\hline Risk Factors & Category & $\mathbf{N}$ & $\%$ & MRS* & $S^{* *}$ \\
\hline Age (year) & Over 60 years & 445 & 100.0 & 371.04 & 28.7 \\
\hline \multirow[t]{5}{*}{ Familial Breast Cancer History } & No & 373 & 83.6 & 179.8 & 29.1 \\
\hline & $\begin{array}{l}\text { One maternal and or paternal } \\
\text { aunt/grandmother }\end{array}$ & 28 & 6.3 & 261.8 & 94.3 \\
\hline & Mother or sister & 39 & 8.8 & 328.5 & 107.0 \\
\hline & Mother and sister & 4 & 0.9 & 401.3 & 159.2 \\
\hline & Mother and two sisters & 1 & 0.2 & 400.0 & 38.5 \\
\hline \multirow[t]{2}{*}{ Personal breast cancer history } & No & 12 & 2.7 & 549.6 & 48.3 \\
\hline & Yes & 433 & 97.3 & 190.8 & 24.7 \\
\hline \multirow[t]{2}{*}{ Age of giving birth (years) } & First birth before the age of 30 & 420 & 94.4 & 198.0 & 67.8 \\
\hline & First birth after the age of 30 & 25 & 5.6 & 241.0 & 101.9 \\
\hline \multirow[t]{3}{*}{ Menarche age (years) } & $\geq 15$ & 76 & 17.1 & 207.6 & 109.3 \\
\hline & $12-14$ & 340 & 76.4 & 197.3 & 60.4 \\
\hline & $\leq 11$ & 29 & 6.5 & 218.28 & 29.89 \\
\hline \multirow[t]{3}{*}{ Body structure } & Underweight & 97 & 21.8 & 184.7 & 64.7 \\
\hline & Normal & 215 & 48.3 & 195.5 & 76.0 \\
\hline & Overweight & 133 & 29.9 & 219.9 & 58.5 \\
\hline Total & - & 445 & 100.0 & - & - \\
\hline
\end{tabular}

UHOD Number: 1 Volume: 25 Year: 2015 
Table 4. Distribution of the women according to their knowledge level, attitudes and behaviors about breast cancer and screening tests

\section{Characteristics}

Whether or not receiving breast cancer and screening tests N: 445

$\begin{array}{lll}\text { Yes } & 20 & 4.5 \\ \text { No } & 425 & 95.5\end{array}$

Institution/person giving training about breast cancer and screening tests

Family members n: $20^{*}$

Friends $15 \quad 75.0$

Health care personnel

Media

$15 \quad 75.0$

BSE practicing

Yes

No

$18 \quad 90.0$

$20 \quad 100.0$

$\mathrm{N}: 445$

$5 \quad 1.1$

$440 \quad 98.9$

Reasons not practicing BSE n: $440 *$

Laziness-negligence $\quad 440 \quad 100.0$

Fear of discovering lump $\quad 440 \quad 100.0$

Lack of knowledge on BSE $\quad 420 \quad 95.4$

The idea that BSE was an $\quad 440 \quad 100.0$

unnecessary practice

Having mammography N: 445

$\begin{array}{lll}\text { Yes } & 15 & 3.4\end{array}$

No $\quad 430 \quad 96.6$

Reasons not having mammography n: $430^{*}$

$\begin{array}{lll}\text { Painful procedure } & 180 & 40.4\end{array}$

Embarrassment $\quad 430 \quad 96.6$

Laziness-negligence $\quad 440 \quad 98.8$

Fear of discovering lump $\quad 445 \quad 100.0$

Beliefs $\quad 380 \quad 85.4$

Lack of knowledge on mammography $430 \quad 96.6$

*Percentages were calculated with $n$ because more than one answer was given.

of those who gave their first birth before the age of $30(94.4 \%)$ was $198.04 \pm 67.77$. The rate of those whose menarche age was $\leq 11$ years was $6.5 \%$. MRS of those whose menarche age $(6.5 \%)$ was $\leq$ 11 years was $218.28 \pm 29.89$, MRS of those whose menarche age (76.4\%) was between 12 and 14 years was $197.31 \pm 60.43$ and MRS of those whose menarche age $(17.1 \%)$ was $\geq 15$ years was 207.63 \pm 109.02 . It was noted that nearly one third of the women $(29.9 \%)$ were overweight. MRS of those who were overweight was $219.85 \pm 58.48$, MRS of those who were of normal weight $(48.3 \%)$ was

\begin{tabular}{|ll|}
\hline $\begin{array}{l}\text { Table 5. Distributions of women's mean scores obtained } \\
\text { from HBMS subscales }\end{array}$ \\
\hline Mean HBMS scores of subscales & $\mathbf{\pm}$ SD \\
\hline Susceptibility & $3.63 \pm 0.81$ \\
Seriousness & $6.33 \pm 0.95$ \\
Health motivation & $10.88 \pm 0.63$ \\
Benefits of BSE & $5.98 \pm 1.56$ \\
Barriers to BSE & $35.45 \pm 2.45$ \\
BSE self-efficacy & $12.34 \pm 1.08$ \\
Benefits of mammography & $15.55 \pm 2.33$ \\
Barriers to mammography & $48.55 \pm 9.36$ \\
SD: Standart Deviation & \\
\hline
\end{tabular}

195.51 \pm 76.05 and MRS of those who were of underweight (21.8\%) was $184 \pm 64.74$ (Table 3).

When the findings related to participant women's health beliefs and attitudes about breast cancer and screening tests were investigated it was found out that nearly all of the women $(98.8 \%)$ did not practice BSE, did not have mammography $(96.6 \%)$ and did not receive training about breast cancer and screening tests $(95.5 \%)$. Those who received training about breast cancer and screening tests obtained information through media (100.0\%) and health care personnel $(90.0 \%)$. The reasons why women did not practice BSE were as follows: fear of discovering lump (100.0\%), laziness-negligence (100.0\%), lack of knowledge on BSE (95.4\%) and the idea that BSE was an unnecessary practice $(100.0 \%)$. The reasons why women did not receive mammography were as follows: fear of discovering lump (100.0\%), laziness-negligence $(98.8 \%)$, lack of knowledge on mammography (96.6\%), embarrassment (96.6\%) and beliefs (85.4\%) (Table 4).

When the distributions of participant women's mean scores obtained from HBMS were investigated the mean score for susceptibility was 3.63 \pm 0.81 , mean score for seriousness was $6.33 \pm 0.95$, mean score for health motivation was $10.88 \pm 0.63$, mean score for benefits of BSE was $5.98 \pm 1.56$, mean score for barriers of BSE was 35.45 \pm 2.45 , mean score for BSE self-efficacy was $12.34 \pm 1.08$, mean score for benefits of mammography was $15.55 \pm 2.33$ and mean score for barriers to mammography was $48.55 \pm 9.36$. In light of these find- 
International Journal of Hematology and Oncology

\begin{tabular}{|c|c|c|c|c|}
\hline \multirow[t]{4}{*}{ HBMS subscales } & \multicolumn{4}{|c|}{ Breast cancer risk levels } \\
\hline & Low & Moderate & High & Very high \\
\hline & n:355 & $\mathrm{n}: 71$ & $\mathrm{n}: 7$ & $n: 12$ \\
\hline & $X \pm S D$ & $X \pm S D$ & $X \pm S D$ & $X \pm S D$ \\
\hline \multirow[t]{2}{*}{ Susceptibility } & $3.10 \pm 0.70$ & $3.22 \pm 0.84$ & $3.45 \pm 1.04$ & $3.72 \pm 0.90$ \\
\hline & \multicolumn{3}{|c|}{ Kruskal Wallis: 62.275, p: 0.000} & \\
\hline \multirow[t]{2}{*}{ Seriousness } & $5.30 \pm 0.95$ & $6.47 \pm 1.025$ & $6.02 \pm 0.87$ & $5.40 \pm 0.95$ \\
\hline & \multicolumn{3}{|c|}{ Kruskal Wallis: 5.257, p: 0.154} & \\
\hline \multirow[t]{2}{*}{ Health motivation } & \multirow[t]{2}{*}{$8.89 \pm 0.62$} & $9.08 \pm 0.69$ & $9.26 \pm 0.57$ & $10.22 \pm 0.30$ \\
\hline & & skal Wallis: 9.4 & & \\
\hline \multirow[t]{2}{*}{ Benefits of BSE } & \multirow[t]{2}{*}{$5.06 \pm 0.95$} & $4.87 \pm 1.02$ & $4.56 \pm 0.87$ & $5.56 \pm 0.86$ \\
\hline & & kal Wallis: 4.7 & & \\
\hline \multirow[t]{2}{*}{ Barriers to BSE } & \multirow[t]{2}{*}{$30.0 \pm 0.95$} & $28.04 \pm .1 .23$ & $33.56 \pm 0.45$ & $32.21 \pm 0.74$ \\
\hline & & kal Wallis: 4.2 & & \\
\hline \multirow[t]{2}{*}{ BSE self-efficacy } & \multirow[t]{2}{*}{$9.23 \pm 0.95$} & $10.34 \pm 0.89$ & $9.45 \pm 1.23$ & $9.34 \pm 0.89$ \\
\hline & & skal Wallis: 5.3 & & \\
\hline \multirow[t]{2}{*}{ Benefits of mammography } & \multirow[t]{2}{*}{$15.00 \pm 0.95$} & $18.00 \pm .0 .23$ & $16.53 \pm 0.33$ & $16.21 \pm 0.67$ \\
\hline & & skal Wallis: 3.2 & & \\
\hline \multirow[t]{2}{*}{ Barriers to mammography } & \multirow[t]{2}{*}{$45.00 \pm 0.75$} & $42.40 \pm 0.45$ & $47.00 \pm 0.25$ & $44.00 \pm 0.34$ \\
\hline & & skal Wallis: 4.2 & & \\
\hline
\end{tabular}

ings the participant women's mean scores obtained from susceptibility, seriousness, health motivation, benefits of BSE, BSE self-efficacy, benefits of mammography were low while their scores for barriers to BSE and barriers to mammography were high (Table 5). According to the findings related to women's mean scores about HBMS subscales in terms of breast cancer risk level it was found out that as women's breast cancer risk level increased so did their mean scores of HBMS susceptibility and health motivation. This difference was statistically significant $(p<0.05)$. The difference between breast cancer risk level and HBMS seriousness, benefits of BSE, barriers to BSE, BSE self-efficacy, benefits of mammography and barriers to mammography was statistically insignificant $(p>0.05)$ (Table 6).

\section{DISCUSSION}

Global aging of world's population increases the incidence of important health problems like cancer. According to the international cancer data, all types of cancers are seen more among the old people as compared with young people as they grow older. ${ }^{1-4}$ Particularly because age of women is longer than men, they suffer from chronic diseases and gynecological cancers more in old age. The most frequent death caused by cancer among the women aged $\geq 65$ years is breast cancer. ${ }^{10}$

Breast cancer incidence is nearly $0.2 \%$. The incidence is 160 per 100.000 between the age of 50 and 60 while it is 200 per 100.000 between the age of 65 and $74 .{ }^{6}$ In western societies, according to the cancer statistics of 2003, one of the 14 women aged between 60 and 79 had breast cancer between 
1997 and 1999. ${ }^{10}$ Breast cancer incidence in Turkey is 79.5 per 100.000 between the age of 40 and 44127.9 per 100.000 between the age of 65 and 69, 125.9 per 100.000 between the age of 70 and 74 and 132.8 per 100.000 between the age of 75 and $79 .^{7}$

In our study it was noted that $2.7 \%$ of the women aged $\geq 65$ years had personal breast cancer history. When we compared our findings to those above mentioned it may be suggested that women in our sample group presented lower malignancy as compared with western societies but higher malignancy as compared with Turkish incidence. We were of the opinion that the reason of the high malignancy in our study was perhaps small number of the sample and the fact that the study was conducted with women who generally came to the hospital for diagnostic purposes.

In our study, it was seen that most of the women belonged to low level of breast cancer risk (79.8\%) while $16.0 \%$ of the women were in the moderate risk group and $1.6 \%$ of them (n: 7) were in the high risk group and $2.7 \%$ of them (n: 12$)$ were in the very high risk group in terms of breast cancer. When the relevant studies were examined it was seen in the study of Tümer and Bayek that $96.3 \%$ of the women belonged to low level of breast cancer risk group, $3.1 \%$ of the women were in the moderate risk group, $0.3 \%$ of them were in the high risk group and $0.3 \%$ of them were in the very high risk group in terms of breast cancer. ${ }^{16}$ Similarly the study of Eroğlu et al. demonstrated that $94.4 \%$ of the participant women belonged to low breast cancer risk group, $4.9 \%$ of the women were in the moderate risk group, $0.4 \%$ of them were in the high risk group and $0.3 \%$ of them were in the very high risk group in terms of breast cancer. ${ }^{17} \mathrm{We}$ were of the opinion that the reason why our study findings differed from the findings of the studies was that the cases in the above mentioned studies were younger.

According to the literature risk factors that play a role in the development of breast cancer are being female, old age, positive mutant genes (BRCA-1 and BRCA-2), familial breast cancer history, overweight $\left(\right.$ BMI $>25 \mathrm{~kg} / \mathrm{m}^{2}$ ), nulliparity, giving the first birth after the age of 30, long term use of con- traceptives and hormone replacement treatment. ${ }^{8,9}$

Breast cancer development risk increases in the residual breast tissue by 4-6 times more after the treatment among those with personal breast cancer risk. It is known that BRCA1, BRCA2, p53, PTEN or other gene mutations correlated with breast cancer increase breast cancer risk. Particularly positive mutant genes of BRCA1 and BRCA2 are responsible for 5-10 of all breast cancers. ${ }^{18,19}$ Similar to the literature breast cancer risk levels of the women with breast cancer history were very high (MRS: $549.58 \pm 48.26$ ).

According to the literature having first degree relatives with breast cancer increases the risk by 1.80 times. In case of having two first degree relatives with breast cancer the risk increases by 2.9 times..$^{20}$ Similarly, MRS of the women who had familial breast cancer history was higher than those who did not have familial breast cancer history. In our study those whose mothers and sisters had breast cancer history had high breast cancer risk while those whose maternal and paternal aunts and grandmothers had breast cancer history had moderate breast cancer risk. In accordance with our study results the studies of Tsuchiya et al., Colditz et al. and Ozmen et al. reported that breast cancer risk was higher among the first degree relatives of those who had breast cancer than the first degree relatives of those who did not have breast cancer. ${ }^{13,21,22}$

Estrogen hormone -an ovarian hormone- affects breast epithelium tissue during fertile period. Therefore in the cases of early menarche ( $<12$ years) and late menopause ( $>55$ years), increase in the exposure time of estrogen hormone increases breast cancer risk. ${ }^{13,23,24}$ Similarly, breast cancer MRS of those whose menarche age was $\leq 11$ years was higher than other women (MRS: 218.28 \pm 29.89 ). These women's breast cancer risk level was moderate. Also breast cancer MRS of those who gave birth after the age of $30(241.00 \pm 101.86)$ was higher than those who gave birth before the age of 30 . Breast cancer risk level of those who gave birth before the age of 30 was low whereas breast cancer risk level of those who gave birth after the age of 30 was moderate. Concurring with our study results the study of Ozmen et al. pointed out that the rate of nulliparity and giving birth after the age of 
35 among the women who had breast cancer was higher than those who did not have breast cancer. ${ }^{13}$

Postmenopausal breast cancer is seen more among the overweight and obese women. ${ }^{13}$ Similarly it was noted in our study that as the BMI increased so did breast cancer MRS. Concurring with our study results the study of Libby et al. (2002) pointed out that among HRT non-users, overweight women (baseline body mass index (BMI >31.1) had an elevated risk of postmenopausal breast cancer compared to slimmer women (baseline BMI $\leq 22.6$ ). ${ }^{25}$ The study of Ozmen et al. reported that women with breast cancer had higher BMI as compared with those without breast cancer (BMI $\geq 25$ ). ${ }^{13}$

In the study it was found out that mean HBMS scores of the participant women for susceptibility, seriousness, health motivation, benefits of breast self-exam (BSE), BSE self-efficacy, mammography benefits were lower whereas their mean HBMS scores for barriers to BSE and mammography were high. It was noted in the study that as women's breast cancer risk level went up so did their mean HBMS scores for susceptibility and health motivation. Accordingly it may be suggested that the participant women were not susceptible enough to and did not care about breast cancer. Besides the participants' health motivation about breast cancer was low, too. The participant women did not believe enough benefits of BSE, benefits of mammography and BSE self-efficacy in detecting breast cancer. Also, their perceptions about barriers to BSE and mammography were high. Therefore it may be concluded that breast cancer susceptibility of the women who participated in the study was low and they abstained from screening methods such as BSE and mammography. Other findings supported this result and nearly all of the participants did not practice BSE and receive mammography. Also the women did not show any tendency towards BSE and mammography. According to the literature the rate of practicing BSE by the women in American and European countries was higher as compared to the women in Asian and African countries. ${ }^{26-29}$ Likewise, the relevant studies indicated that most of the women did not practice BSE regularly and those who practiced BSE at times practiced BSE incorrectly. ${ }^{30-33}$ Meanwhile, it was noted in this study that women's perceptions about barriers to mammography was higher. ${ }^{30-33}$ According to the literature women's most important reasons related to the negative opinions and attitudes about early detection methods of breast cancer are fear of discovering lump and the idea that breast cancer is an incurable disease. ${ }^{26-29,30-33}$ Likewise nearly all of the women in our study told that they did not practice BSE and have mammography due to the fear of discovering lump. Other reasons why women abstain from early detection methods are laziness-negligence, lack of knowledge on BSE, embarrassment and the idea that BSE was an unnecessary practice. These findings demonstrated that the participant women did not have positive health beliefs and attitudes. However it was found out that as the participant women's breast cancer risk level increased so did their HBMS susceptibility and health motivation. In other words women with high breast cancer risk level were more susceptible to breast cancer and their health motivation was higher. Similarly the relevant studies reported that women who had personal breast cancer history or whose family members had breast cancer history or those with high breast cancer risk demonstrated higher level of breast cancer awareness/ susceptibility and health motivation. ${ }^{34,35}$ Our study finding concurred with the literature.

As a result it was found out that $1.6 \%$ of the women were under high risk while $2.7 \%$ of them were under very high risk for breast cancer. Breast cancer risk level of those whose mothers and sisters had breast cancer history was high (MRS: 328.46 $\pm 107.02)$. As a conclusion in the study it was revealed that the participant women's HBMS scores for susceptibility, seriousness, health motivation, benefits of breast self-exam (BSE), BSE self-efficacy, mammography benefits were lower whereas their mean HBMS scores for barriers to BSE and mammography were high. In light of the findings obtained from the study the following recommendation may be made:

- At early diagnosis centers like Early Diagnosis and Screening Center for Cancer and geriatrics polyclinics breast cancer risk analyses should be provided for those aged $\geq 65$, risk groups should be detected, early diagnosis methods should be popularized and planned training and counseling services should be provided by physicians/nurses 
for the risk groups in order to increase awareness of breast cancer.

- Evidence-based studies with larger samples and control groups should be conducted in different ethnic and cultural regions because we think this will increase the reliability of the results.

\section{REFERENCES}

1. Shrestha LB. Population aging in developing countries. Health Aff (Millwood) 19: 204-212, 2000.

2. Jemal A, Siegel R, Ward E, et al. Cancer statistics, 2006. CA Cancer J Clin 56: 106-130, 2006.

3. Jemal A, Siegel R, Ward E, et al. Cancer statistics, 2008. CA Cancer J Clin 58: 71-96, 2008.

4. Jemal A, Siegel R, Ward E, et al. Cancer statistics, 2009. CA Cancer J Clin 59: 225-249, 2009.

5. Kimmick GG, Balducci L. Breast cancer and aging. Hematol Oncol Clin North Am 14: 213- 233, 2000.

6. Edward $\mathrm{NI}$, Jones DA. Uptake of breast cancer screening in older women. Age and Aging 29: 131-135, 2000.

7. The Ministry of Health of Turkey. Health Statistics Yearbook 2010. Mollahaliloglu S, Basara BB, Eryilmaz Z (eds). Ankara, Kalkan Press, 2011: 25.

8. Gross RE. Breast cancer: Risk factors, screening, and prevention. Semin Oncol Nurs 16: 176-84, 2000.

9. Vogel VG. Breast cancer prevention: A review of current evidence. CA. Cancer J Clin 50: 156-170, 2000.

10. Kimmick GG, Muss HB. Breast cancer in older patients. Semin Oncol 31: 234-248, 2004.

11. Elverici E, Barça AN, Düzegün AP, et al. Breast Imaging Findings among the women patients in the geriatric age group. TJG 10: 1-4, 2007.

12. Arslan Ç, Kilickap S, Dede DS, et al. Frequency of cancer types in patents aged 65 and older: results from cancer registry data base of Hacettepe University Hospitals. TJG 14: 187-192, 2011.

13. Ozmen V, Ozcinar V, Karanlik H, et al. Breast cancer risk factors in Turkish women - a University Hospital based nested case control study. World J Surg Oncol 8: 37, 2009.

14. Spence WR. Health EDCO. Inc, Waco, Texas, A Division of WRS Group, 2000.

15. Champion VL. Instrument Development for Health Belief Model Constructs. Advance in Nursing Science 6: 73-85, 1984.

16. Tümer $A$, Bayek $H$. Çalisan kadinlarda meme kanseri risk düzeyi. J Breast Health 6: 17-21, 2010.
17. Eroglu C, Eryilmaz MA, Civcik S, Gurbuz Z. Breast Cancer Risk Assessment: 5000 Cases. UHOD 20: 27-33, 2010.

18. Fisher B, Dignam J, Wolmark N, et al. Tamoxifen in treatment of intraductal breast cancer: National surgical adjuvant breast and bowel project B-24 randomized controlled trial. Lancet 353: 1993-2000, 1999.

19. Martin AM, Weber BL. Genetic and hormonal risk factors in breast cancer. J Natl Cancer Inst 92: 1126- 1135, 2000.

20. Collaborotive Group on Hormonal Factors in Breast Cancer Familial breast cancer. Collaborative reanalysis of individual data from 52 epidemiological studies including 58,209 women with breast cancer and 101,986 women without the disease. Lancet 358: 1389-1399, 2001.

21. Colditz GA, Rosner BA, Speizer FE. Risk factors for breast cancer according to family history of breast cancer for the Nurses' Health Study Research Group. JNCI 8: 1003-1004, 1996.

22. Tsuchiya M, Iwasaki M, Otani $\mathrm{T}$, et al. Breast cancer in firstdegree relatives and risk of lung cancer: assessment of the existence gene sex interactions. Jpn J Clin Oncol 37: 419423, 2007.

23. McPherson K, Steel C, Dixon JM. Breast cancer -Epidemiology, risk factors, and genetics. BMJ 321: 624-628, 2000.

24. Shantakumar S, Terry MB, Teitelbaum SL, et al. Reproductive factors and breast cancer risk among older women. Breast Cancer Res Treat 102: 365-374, 2007.

25. Libby M, White E, Chen Z, et al. Obesity, body size, and risk of postmenopausal breast cancer: the Women's Health Initiative (United States) Cancer Causes and Control 13: 741-751, 2002.

26. Oluwatosin OA, Oladepo O. Knowledge of breast cancer and its early detection measures among rural women in Akinyele Local Government Area, Ibadan, Nigeria. BMC Cancer 6: 271, 2006.

27. Petro-Nustus W, Mikhail Bl. Factors associated with breast self-examination among Jordanian women. Public Health Nursing 19: 263-271, 2002.

28. Rosvold OE, Hjartaker A, Bjertness E, et al. Breast self-examination and cervical cancer testing among Norwegian female physicians a nation-wide comparative study. Soc Sci Med 52: 249-258, 2001.

29. Jarvandi S, Montazeri A, Harirchi I, et al Beliefs and behaviors of Iranian teachers toward early detection of breast cancer and breast self-examination. Public Health 116: 245-249, 2002.

30. Kanaga KC, Nithiya J, Shatirah MF. Awareness of breast cancer and screening procedures among Malaysian women. Asian Pac J Cancer Prev 12: 1965- 1977, 2011.

31. Karadagi G, Güngörmüs Z, Sürücü R, et al. Awareness and practices regarding breast and cervical cancer among turkish women in Gaziantep. Asian Pac J Cancer Prev 15: 10931098, 2014. 
International Journal of Hematology and Oncology

32. Parsa P, Kandiah M, Mohd Zulkefli NA, et al. Knowledge and behavior regarding breast cancer screening among female teachers in Selangor, Malaysia. Asian Pac J Cancer Prev 9: 221-227, 2008.

33. Duman NB, Büyükgönenc L, Pinar G. Health beliefs of the female academicians about breast cancer and screening tests and the affecting factors. UHOD 23: 233-241, 2013.

34. Ceber E, Mermer G, Okcin F, et al. Breast cancer risk and early diagnosis applications in Turkish women aged 50 and over. Asian Pac J Cancer Prev 14: 5877-5882, 2013.

35. Powe BD, Underwood S, Canales M, et al. Perceptions about breast cancer among college students: Implications for nursing education. J Nurs Educ 44: 257-265, 2005.

\section{Correspondence}

Nuriye Büyükkayacı DUMAN

Hitit Üniversitesi Sağlık Bilimleri Yüksek Okulu

ÇORUM / TURKEY

Tel: (+90.364) 2230730 / 3530

Fax: (+90.364) $2230730 / 3531$

email: nurfatihh@hotmail.com 